Tadeusz Branecki

Chełm

\title{
SYSTEM USTROJOWY KANTONU BERNO
}

Kanton Berno jest "stanem” w Konfederacji Szwajcarskiej ${ }^{1}$ - brzmi art. 2 ust. 1 konstytucji kantonalnej z dnia 6 czerwca 1993 roku². Oprócz tego wyrazu na określenie swojego statusu prawno-państwowego używa Berno także pojęcia „państwo" (Staat) ${ }^{3}$. Zgodnie z art. 1 ust. 1 konstytucji kanton jest "wolnościowym, demokratycznym $i$ socjalnym państwem prawa". Podobnie, jak pozostałe kantony, również Berno posiada gwarancję suwerenności udzieloną przez konstytucję federalną z 1999 roku, której art. 3 stanowi: „Kantony sa suwerenne, o ile ich suwerenność nie została ograniczona przez Konstytucję Federalna; wykonuja te wszystkie prawa, które nie zostały przekazane Federacji"'.

Uznanie kantonów za niezależne podmioty (państwa) ${ }^{5}$ wynika również z treści innych artykułów konstytucji federalnej:

a) art. 1 - uznaje on Naród szwajcarski i kantony za twórców Konfederacji Szwajcarskiej;

${ }^{1} \mathrm{~W}$ niemieckojęzycznej wersji konstytucji federalnej występuje wyraz „Eidgenossenschaft” oznaczający w dosłownym tłumaczeniu "zwiazek ustanowiony pod przysiega" - A. Baur, Szwajcarski fenomen, Warszawa 1992, s. 14; inne tłumaczenie tego wyrazu to „Sprzysiężenie” - P. Sarnecki, Zgromadzenie Federalne. Parlament Konfederacji Szwajcarskiej, Warszawa 2003, s. 3.

${ }^{2}$ Opublikowana w Systematycznym Zbiorze Prawa Federalnego SR-131.212 (Systematische Sammlung des Bundesrechts) i dostępna online pod adresem http://www.admin. ch/ch/d/sr/c131_212.html (31 grudnia 2012) i http://www.sta.be.ch/belex/d/1/101_1.html (31 grudnia 2012 r.).

${ }^{3}$ Wcześniej na określenie kantonu używano pojęcia „stan” (Stand), a pierwotnie „miejscowość" (Ort) - Z. Czeszejko-Sochacki, System konstytucyjny Szwajcarii, Warszawa 2002, s. 5. Wyraz „stan” używany jest obecnie w nazwie izby wyższej parlamentu federalnego (Ständerat).

${ }^{4}$ Konstytucja federalna Konfederacji Szwajcarskiej z dnia 18 kwietnia 1999 r., tłumaczenie i wstęp Z. Czeszejko-Sochacki, Warszawa 2000, s. 42.

5 A. Baur, op. cit., s. 40 („Kantony sa państwami i same używaja w stosunku do siebie tej nazwy"); Z. Niewiadomski, Gmina w Szwajcarii. Studium ustrojowo-prawne, Warszawa 1993, s. 9 ("Konfederacja Szwajcarska składa się z 26 odrębnych państw"). 
b) art. 48 ust. 1 - przyznaje kantonom prawo do zawierania pomiędzy sobą umów, tworzenia organizacji i instytucji;

c) art. 51 ust. 1 - kantony mogą nadawać sobie demokratyczne konstytucje (muszą być one zaakceptowane przez naród i znowelizowane na żądanie większości wyborców - ponadto wymagają także gwarancji Federacji, która jest udzielana, jeżeli nie są sprzeczne z prawem federalnym);

d) art. 53 ust. 1 i 2 - gwarantuje kantonom ochronę ze strony Federacji dla ich istnienia i ich terytorium (zmiana ilości i pozycji kantonu wymaga zgody zainteresowanej ludności, zainteresowanego kantonu oraz Narodu szwajcarskiego i pozostałych kantonów) ${ }^{6}$;

e) art. 56 ust. 1 - przyznaje kantonom prawo do zawierania umów z zagranicą (umowy te nie mogą pozostawać w sprzeczności z interesami Federacji, jak również innych kantonów - kantony mają także obowiązek powiadamiania Federacji przed ich zawarciem).

Obecnie kantony określa się mianem „autonomicznych politycznie wspólnot terytorialnych o ograniczonej państwowości"7.

Kanton Berno uznaje siebie za centrum (środek) pomiędzy Szwajcarią niemiecko- i francuskojęzyczną. Skutkiem tego jest, m.in. używanie przez kanton dwóch języków urzędowych: niemieckiego i francuskiego ${ }^{8}$. Kanton leży w zachodniej części Szwajcarii, granicząc na północy z Jurą i Solurą, na wschodzie - z Uri, Nidwalden, Obwalden, Lucerną i Argowią, na południu z Wallis, a na zachodzie Neuenburgiem, Fryburgiem i Waadt. Zajmuje powierzchnię $5959 \mathrm{~km}^{2}$, co oznacza, że jest drugim co do wielkości kantonem szwajcarskim ${ }^{9}$. Zamieszkuje go 974235 mieszkańców (2009 r.) - zajmuje również drugie (po Zurychu) miejsce w statystyce ludnościowej. Stolica kantonu miasto Berno jest jednocześnie stolicą Konfederacji Szwajcarskiej (od 1848 r.).

Herb stolicy jest jednocześnie herbem kantonu. Jest nim czarny niedźwiedź widoczny z lewego profilu (widać wszystkie łapy, których pazury, podobnie jak i męskość oraz język są koloru czerwonego) znajdujący się na żółtym polu, które nad nim i pod nim oddzielone jest od pól czerwonych dwoma (przebiegającymi ukośnie w dół w prawo) czarnymi liniami.

Sama nazwa miasta Berno (założonego w 1191 r. przez księcia Bertolda $\mathrm{V}$ z rodu Zähringen) pochodzi od legendy związanej z polowaniem

${ }^{6}$ Udzielona uchwałą federalną z dnia 22 września 1994 r. o gwarancji dla Konstytucji Kantonu Berno - M. Aleksandrowicz, System prawny Szwajcarii. Historia i współczesność, Białystok 2009, s. 174.

7 P. Tschannen, Staatsrecht der Schweizerischen Eidgenossenschaft, Berno 2011, s. 237; wcześniej odmawiano im uznania za państwo z uwagi, m.in. na podległość Federacji, określenie zakresu władzy kantonalnej przez konstytucję federalną, co oznaczało brak ich suwerenności - M. Aleksandrowicz, op. cit., s. 97.

${ }^{8}$ Podobne dwujęzyczne kantony to Fryburg i Wallis.

${ }^{9}$ Większa jest tylko Gryzonia zajmująca obszar 7105 km². 
księcia na terenie obecnego miasta o zabiciem niedźwiedzia - co podkreślone zostało w jego nazwie (Bär - niedźwiedź) $)^{10}$. Od roku 1218 Berno było wolnym miastem cesarskim, zaś członkiem Federacji zostało w roku $1353^{11}$.

Owczesna Federacja powstawała w drodze umów zawieranych pomiędzy tworzącymi ją kantonami - 6 marca 1353 roku zawarta została umowa Berna z Uri, Schwyz i Unterwalden. Z pozostałymi wchodzącymi wówczas w skład Federacji kantonami zawarło umowy kilkadziesiąt lat później - w roku 1421 (Lucerna) i 1423 roku (Zurych). Warto wspomnieć, że Berno było przez pewien okres siedzibą jedynego organu Federacji Sejmu Federalnego (Tagsatzung) ${ }^{12}$.

W roku 1528 w Bernie utworzono Chrześcijańską Unię Miast (Bazylea, Miluza, Biel, Berno, Zurych, St. Gallen i Konstancja) skupiającą miasta należące do Reformacji ${ }^{13}$. W trakcie dwóch wojen religijnych (kappelskich) w latach 1529 i 1531 miasto stanęło po stronie pokonanych wówczas zwolenników Reformacji. Prymat kantonów katolickich w Federacji zakończyła II wojna willmergska i zwycięstwo wojsk Berna oraz Zurychu w bitwie pod Villmergen (15 lipca 1712 r.).

W roku 1797 wojska Berna próbowały zatrzymać wkraczającą do Szwajcarii armię francuską ${ }^{14}$, ale poniosły klęskę w bitwie pod Grauholz. Rok później utworzono na ziemiach szwajcarskich Republikę Helwecką - wchodzące w jej skład kantony utraciły swoją odrębność i stały się odpowiednikami francuskich departamentów. Będąca podstawą ustroju kraju Konstytucja Helwecka (Helvetische Verfassung) wymieniała w art. 18 Berno, jako jeden z kantonów tworzących Republikę ${ }^{15}$ - jednakże jego obszar nie obejmował podległych mu wcześniej terenów Argowii i Waadt.

${ }^{10}$ C. Schaub, E.H. Gaullieur, Die Schweiz, Ihre Geschichte, Geographie und Statistik, nebst einem Ueberblick über die Alterthürner, Literatur, Kunst, und die Industrie der zweiundzwanzig Kantone. Zweite Abteilung: Die Malerische Schweiz, Genewa i Bazylea 1857, s. 142-143.

11 W. Oechsli, Quellenbuch zur Schweizergeschichte. Für Haus und Schule, Zurych 1886, s. 95-97.

12 Było to coroczne spotkanie przedstawicieli wszystkich członków Federacji, podczas którego podejmowane były decyzje w przedmiocie polityki zagranicznej, bezpieczeństwa mieszkańców, obrony Federacji oraz rozpoznawano spory miejscowości i spory prywatne - J. Wojtowicz, Historia Szwajcarii, Wrocław 1976, s. 53.

${ }^{13}$ W 1528 roku odbyła się w Bernie dysputa religijna z udziałem jednego z największych przedstawicieli szwajcarskiej Reformacji Huldrycha Zwingliego, po której miasto rozpoczęło reformy oparte na jej przesłaniu - T. Branecki, Udział Zwingliego w życiu polityczno-prawnym XVI wiecznego Zurychu i jego wptyw na wybuch wojen religijnych (kappelskich), „Zamojskie Studia i Materiały”, zeszyt 1, Zamość 2001, s. 80.

14 Przyczyną wkroczenia do Szwajcarii wojsk francuskich było antyberneńskie powstanie na podlegających Bernu ziemiach Waadt - powstańcy utworzyli wówczas Republikę Leman i wezwali na pomoc Francuzów.

${ }_{15}$ Konstytucja Republiki Helwecji z 12 kwietnia 1798 roku [w:] Najstarsze konstytucje z końca XVIII i I połowy XIX wieku, wybrał, przełożył i wstępem opatrzył P. Sarnecki, Warszawa 1997, s. 90-111. 
Pierwsza konstytucja kantonu Berno znalazła się w rozdziale IV Aktu Mediacyjnego (1803) ${ }^{16}$ - konstytucji narzuconej Szwajcarom przez Napoleona Bonaparte. Zgodnie z brzmieniem art. 1 rozdziału XX Aktu (będącego konstytucją Szwajcarii) Berno było jednym z 19 kantonów, które były od siebie niezależne i gwarantowały sobie wzajemnie własne konstytucje, terytorium oraz wolności ${ }^{17}$.

Kolejna konstytucja szwajcarska - Umowa Związkowa z 1815 roku - wprowadziła w kraju instytucje „kantonu dyrektorialnego" (Vorort); w kantonie tym zbierał się na obrady Sejm Federalny, a szef rządu kantonu (Landamann) był quasi-prezydentem kraju. Stolica kantonu dyrektorialnego pełniła także rolę stolicy kraju - jednym z 6 kantonów dyrektorialnych zostało także Berno.

Kolejne (po rozdziale IV Aktu Mediacyjnego) konstytucje kantonu Berno pochodziły z 6 lipca 1831 r., 31 lipca 1846 r. i 4 czerwca 1893 r.

Warto wspomnieć, że w roku 1978 z północnych ziem kantonu Berno utworzono (po przeprowadzeniu referendum) kanton Jura, który od 1 stycznia 1979 r. stał się najmłodszym, 26. członkiem Konfederacji Szwajcarskiej.

Obecnie obowiązująca konstytucja kantonalna pochodzi z 6 czerwca 1993 r. i składa się ze 135 artykułów podzielonych na 10 rozdziałów: I - „Postanowienia ogólne” (art. 1-8), II - „Prawa zasadnicze, prawa i cele socjalne” (art. 9-30), III - „Zadania publiczne” (art. 31-54), IV - „Prawa obywatelskie" (art. 55-65), V - „Władze kantonalne” (art. 66-100), VI - „Finanse” (art. 101-106), VII - „Gminy” (art. 107-120), VIII - „Kościoły krajowe i inne wspólnoty wyznaniowe" (art. 121-126), IX - „Rewizja konstytucji” (art. 127-129) i X - „Przepisy przejściowe i końcowe” (art. 130-135).

Rozdział drugi konstytucji zawiera obszerny katalog praw zasadniczych, wymieniając wśród nich:

- ochronę godności człowieka (art. 9);

- równość wobec prawa (dotyczy obu płci) ${ }^{18}$ i zakaz dyskryminacji ze względu na rasę, kolor skóry, płeć, język, pochodzenie, poglądy polityczne, przekonania religijne (art. 10);

- ochronę przed arbitralnością państwa - ochronę dobrej wiary (art. 11);

- gwarancje dla praw osobistych: wolności osobistej, swobody przekonań, swobody osiedlania się oraz zakaz stosowania tortur oraz nieludzkiego i poniżającego traktowania (art. 12);

- ochronę małżeństwa i życia rodzinnego oraz prawa do swobodnego wyboru innej formy wspólnego życia (art. 13);

\footnotetext{
${ }^{16}$ Rozdziały I-XIX zawierały teksty poszczególnych konstytucji kantonalnych.

17 A. Kölz, Quellenbuch zur neueren schweizerischen Verfassungsgeschichte, Berno 1992, s. 175.

${ }_{18}$ Obie płcie mają zagwarantowany równy dostęp do publicznych placówek oświatowych i urzędów oraz do jednakowej płacy za jednakową pracę.
} 
- swobodę wyznania i sumienia oraz zakaz zmuszania kogokolwiek do praktyk religijnych albo konfesji (art. 14);

- gwarancję wolności słowa (art. 15);

- gwarancję swobody przemieszczania się i osiedlania (art. 16);

- swobodę głoszenia poglądów i wyrażania opinii (niezależnie od formy) i zakaz stosowania (poza szczególnymi stosunkami prawnymi) cenzury (art. 17);

- prawo do prywatności - każdy ma prawo do wglądu do przetwarzanych danych i żądania ich poprawienia; dane podlegają ochronie przed nieautoryzowanym użyciem, a organy mogą przetwarzać dane osobowe tylko gdy istnieje do tego podstawa prawna, a dane te są niezbędne i konieczne dla wykonywania ich obowiązków (art. 18);

- gwarancję dla wolności zgromadzeń i swobody stowarzyszania się (art. 19);

- prawo składania do władz petycji i zbierania w tym celu podpisów - zobligowanie organów władzy do przyjęcia i odpowiedzi w ciągu roku na złożoną petycję (art. 20);

- swobodę kształcenia i badań naukowych (art. 21);

- gwarancję dla swobody twórczości artystycznej (art. 22);

- gwarancję dla swobody wyboru zawodu i miejsca pracy, swobody działalności gospodarczej oraz tworzenia i należenia do związków zawodowych i zakładowych (art. 23);

- gwarancję dla prawa własności - wywłaszczenie i ograniczenie własności jest dopuszczalne za pełną rekompensatą (art. 24);

- gwarancje dla osób pozbawionych wolności - jej pozbawienie może nastąpić tylko $\mathrm{w}$ przypadkach przewidzianych przez prawo, a każda osoba pozbawiona wolności musi zostać niezwłocznie poinformowana (w zrozumiałym dla niej języku) o przyczynie zatrzymania i przysługujących jej prawach; ponadto każda zatrzymana osoba musi być w możliwie najkrótszym czasie wysłuchana przez organ wymiaru sprawiedliwości, który podejmie dalszym zatrzymaniu; każdy zatrzymany ma też prawo do posiadania obrońcy, szybkiego procesu, a w przypadku bezprawnego lub nieuzasadnionego zatrzymania do odszkodowania lub zadośćuczynienia (art. 25);

- prawo do bezstronnego i niezależnego procesu - zawarte jest w tym prawo do wysłuchania, wydania wyroku w rozsądnym terminie, prawo do odwołania, domniemanie niewinności i rozstrzyganie wątpliwości na korzyść oskarżonego (art. 26).

Każde ograniczenie konstytucyjnych praw podstawowych wymaga podstawy prawnej, która określi jego treść, cel i zakres. Zastrzeżone pozostają przypadki nieuchronnego i oczywistego niebezpieczeństwa, zwłaszcza gdy zagrożone jest życie ludzkie lub zdrowie. Ponadto prawa 
podstawowe mogą być ograniczone tylko wtedy, gdy uzasadnia to ochrona nadrzędnego interesu publicznego lub przeciwne prawo fundamentalne innej osoby fizycznej.

Konstytucja kantonalna w sposób wyraźny wyodrębnia także zadania kantonu, którymi są: ochrona środowiska (art. 31), ochrona krajobrazu (art. 32), zagospodarowanie przestrzenne i budownictwo (art. 33), transport i komunikacja (art. 34), zaopatrzenie w wodę i energię ${ }^{19}$ (art. 35), zapewnienie porządku publicznego i bezpieczeństwa (art. 36), pomoc socjalna dla potrzebujących - prowadzona we współpracy z gminami i organizacjami zarówno publicznymi i prywatnymi (art. 38), walka $\mathrm{z}$ bezrobociem (art. 39), ochrona zdrowia (art. 41), kształcenie i dokształcanie (art. 42), zapewnienie niezależności mediów (art. 46), kultura i sport (art. 48-49), rozwój gospodarki (art. 50), rozwój rolnictwa i leśnictwa (art. 51).

Kanton Berno posiada także swoje regalia, którymi są: wydobycie soli, wody termalne, myślistwo i rybołówstwo.

Prawa obywatelskie w kantonie przysługują wszystkim obywatelom i obywatelkom szwajcarskim, którzy mieszkają w kantonie i ukończyli 18 rok życia. Wybierają oni: ${ }^{20}$

1) parlament kantonalny (Wielka Rada),

2) rząd kantonu (Rada Rządowa),

3) reprezentantów kantonu do parlamentu federalnego - Rady Narodu (26 deputowanych) ${ }^{21}$ i Rady Kantonu (2 deputowanych) ${ }^{22}$.

Konstytucja kantonalna przewiduje możliwość przeprowadzenia nadzwyczajnych wyborów parlamentarnych i wyboru członków rządu na wniosek poparty przez 30 tys. uprawnionych do głosowania obywateli. Nowo wybrany skład obu organów urzęduje do końca kadencji swoich poprzedników.

${ }^{19}$ Przede wszystkim pochodzącą z odnawialnych źródeł.

${ }^{20}$ Konstytucja używa pojęcia "Naród” (Volk).

${ }^{21}$ W kadencji 2011-2015: A. Aebi (SVP: Schweizerische Volkspartei), M. Aebischer (SP: Sozialdemokratische Partei der Schweiz), E. Allemann (SP), A. Amtstutz (SVP), K. Bertschy (GLP: Grünliberale Partei), U. Gasche (BDP: Bürgerlich-Demokratische Partei Schweiz), A.M. Geissbühler (SVP), J. Grossen (GLP), H. Grunder (BDP), U. Haller Vanini (BDP), L. Hess (BDP), R. Joder (SVP), M. Kiener Nellen (SP), C. Markwalder (FDP-Die Liberale), C. Pardini (SP), N. Pierren (SVP), A. Rösti (SVP), R. Rytz (GPS:Grüne Partei der Schweiz), M. Streiff-Feller (EVP: Evangelische Volkspartei der Schweiz), F. Teuscher (GPS), A. Tschäppät (SP), A. von Graffenried (GPS), E. von Siebenthal (SVP), H. Wandfluh (SVP), C. Wasserfallen (FDP-Die Liberalne) i U. Wyss (SP) - http://www.parlament.ch/d/organe-mitglieder/nationalrat/mitglieder-kanton/mitglieder-nr-kanton-be/Seiten/default.aspx, (31 grudnia 2012).

${ }^{22}$ W kadencji 2011-15: W. Luginbühl (BDP) i H. Stöckli (SP) - http://www.parlament. ch/d/organe-mitglieder/staenderat/mitglieder-kanton/mitglieder-sr-kanton-be/Seiten/default.aspx, (31 grudnia 2012). 
W kantonie funkcjonują charakterystyczne dla Szwajcarii instytucje demokracji bezpośredniej jakimi są inicjatywa obywatelska (Volksinitiative) i referendum.

Kantonalna inicjatywa obywatelska dotyczyć może:

1) całkowitej lub częściowej zmiany konstytucji kantonu,

2) uchwalenia, uchylenia lub zmiany prawa,

3) wypowiedzenia lub rozpoczęcia rokowań w sprawie zawarcia lub wprowadzenia zmian $\mathrm{w}$ traktacie międzykantonalnym lub międzynarodowym o ile podlega to referendum,

4) opracowanie decyzji Wielkiej Rady, jeżeli podlega ona referendum.

Inicjatywa dochodzi do skutku, jeżeli w ciągu 6 miesięcy uzyska poparcie 15 tys. wyborców. Z kolei wniosek dotyczący całkowitej zmiany konstytucji wymaga zebrania 30 tys. podpisów.

Inicjatywa może mieć dwojaką postać:

a) prostego wniosku - deklaracji lub

b) przygotowanego projektu - jeśli nie przewiduje całkowitej zmiany konstytucji albo przygotowania decyzji Wielkiej Rady.

Rząd kantonu podejmuje decyzję w sprawie sfinalizowania wniosku inicjatywy, zaś parlament o jej ważności. Inicjatywa będzie w całości lub częściowo uznana za nieważną, gdy:

1) będzie dotyczyła prawa nadrzędnego,

2) jest niewykonalna,

3) nie zachowuje jedności formy i materii.

Wielkiej Radzie przysługuje prawo złożenia kontrpropozycji względem wniosku inicjatywy (Gegenvorschlag). Głosowanie w sprawie wniosku i kontrpropozycji odbywa się jednocześnie - wyborcy mogą uznać za przyjęte obie propozycje i postanowić, jakie preferują rozwiązania.

Referendum kantonalne ma dwojaką postać:

1) referendum obligatoryjnego, któremu podlegają (art. 61):

a) zmiany konstytucji,

b) inicjatywy, których nie popiera Wielka Rada lub które są niezgodne z kontrpropozycją,

c) umowy międzykantonalne i międzynarodowe, które nie są możliwe do pogodzenia z konstytucją,

d) zmiany obszaru kantonu, za wyjątkiem zmiany granic;

2) referendum fakultatywnego, któremu podlegają z kolei (art. 62):

a) ustawy,

b) umowy międzykantonalne i międzynarodowe, które mają $\mathrm{w}$ treści przedmiot, podlegający w kantonie referendum fakultatywnemu,

c) decyzje Wielkiej Rady dotyczące wydatków, o ile odnoszą się do 
wydatków jednorazowych przekraczających 2000000 franków (CHF) lub wydatków powtarzających się ponad $400000 \mathrm{CHF}$,

d) decyzje koncesyjne Wielkiej Rady,

e) uchwały Wielkiej Rady odnoszące się do zasad podstawowych,

f) pozostałe uchwały Wielkiej Rady, o ile przewiduje to prawo lub zażąda tego sama Wielka Rada lub jej 70 członków (referendum nie podlegają wybory, sprawy sądowe, porządek obrad).

Referendum dochodzi do skutku, o ile w ciągu 3 miesięcy od publikacji wniosku poprze go 10000 wyborców. Wniosek zostaje przyjęty, jeżeli zdobędzie większość oddanych ważnie głosów. Wielka Rada może względem wniosku, który podlega referendum przedstawić także wniosek alternatywny (Eventualantrag). W odbywającym się wówczas referendum wyborcom przedstawiane są oba wnioski. Jeżeli Wielka Rada nie przedstawi wniosku alternatywnego 10000 wyborców może również (w ciągu 3 miesięcy od publikacji ustawy lub postanowienia) przedstawić wniosek obywatelski (Volksvorschlag).

Organy władzy kantonalnej w swoich działaniach winny stosować się do następujących zasad:

1) podziału władzy (żaden jej organ nie może być niekontrolowany i posiadać władzę nieograniczoną),

2) związania w swoich działaniach konstytucją i ustawami,

3) niestosowania przez władze sądowe decyzji kantonalnych sprzecznych z prawem nadrzędnym,

4) bierne prawo wyborcze do organów kantonalnej władzy ustawodawczej, wykonawczej i sądowniczej przysługuje każdemu uprawnionemu do głosowania, o ile konstytucja lub ustawy nie przewidują spełnienia dodatkowych wymagań;

5) niepołączalności stanowisk:

- nie można być jednocześnie deputowanym do parlamentu kantonalnego i członkiem rządu kantonu, kantonalnego wymiaru sprawiedliwości, centralnej i lokalnej administracji kantonalnej lub innym urzędnikiem, jeżeli przewidują to ustawy,

- członek kantonalnego wymiaru sprawiedliwości nie może być jednocześnie członkiem rządu kantonu lub administracji kantonalnej,

- członek rządu kantonalnego nie może być jednocześnie deputowanym do parlamentu federalnego;

6) wyłączenia członka organu ze sprawy, która dotyczy go bezpośrednio,

7) uchwalania wszystkich zasadniczych i ważnych kantonalnych spraw w formie ustaw - do tego należą także przepisy, względem których konstytucja wyraźnie przewiduje formę tego aktu prawnego, dotyczące: 
- podstaw statusu prawnego jednostki,

- przedmiotu opłat, podstaw ich ustalania i kręgu podatników za wyjątkiem opłat w najniższej wysokości,

- celu, charakteru i zakresu głównych zadań kantonu,

- podstawy organizacyjnej i zadań organów władzy kantonalnej;

8) informowania przez władze o swojej działalności,

9) odpowiedzialności kantonu i innych podmiotów realizujących zadania publiczne za szkody, które ich organy wyrządzą bezprawnie przy wykonywaniu zadań (inne przypadki odpowiedzialności oraz odpowiedzialność władz i urzędników administracji kantonalnej określą szczegółowe przepisy).

Organem władzy ustawodawczej w kantonie Berno jest jednoizbowy parlament - Wielka Rada (Grosse Rat), składający się ze 160 deputowanych, wybieranych na 4-letnią kadencję (art. 72). W wyborach parlamentarnych obowiązuje ordynacja proporcjonalna, przy czym 12 miejsc zagwarantowanych jest konstytucyjnie dla Jury Berneńskiej. Cały kanton został podzielony na okręgi wyborcze (nie zawsze pokrywają się z obszarem okręgów administracyjnych): Jura bernois (12 miejsc), Biel - Bienne Seeland (26), Oberaargau (12), Emmental (15), Mittelland - Nord (22), Bern (20), Mittelland - Süd (20), Thun (16) i Oberland (17). W okręgach tych ilość mandatów została uzależniona od liczby zamieszkujących dany okręg mieszkańców.

W ostatnich wyborach parlamentarnych (2010 r.) w Wielkiej Radzie znaleźli się przedstawiciele następujących partii politycznych:

1) FDP-Liberałowie $=17$

2) Chrześcijańsko-Demokratyczna Partia Ludowa $(\mathrm{CVP})=1$,

3) Socjaldemokratyczna Partia Szwajcarii $(\mathrm{SP})=35$,

4) Szwajcarska Partia Ludowa (SVP) $=44$,

5) Ewangelicka Partia Szwajcarii/Partia Chrześcijańsko-Socjalna $(\mathrm{EVP} / \mathrm{CSP})=10$,

6) Partia Zieloni-Liberałowie (GLP) $=4$,

7) Partia Mieszczańsko-Demokratyczna $(\mathrm{BDP})=25$,

8) Zieloni (GPS) $=16$,

9) Federalna Unia Demokratyczna $(E D U)=5$,

10) Autonomiczna Partia Socjalistyczna (PSA) $=3^{23}$.

Podstawowym zadaniem parlamentu jest stanowienie prawa - wydawanie ustaw i dekretów (art. 74 ust. 1 konstytucji). Zatwierdza ona również traktaty międzynarodowe i umowy międzykantonalne, o ile nie należą one do wyłącznej właściwości rządu kantonu.

${ }^{23}$ http://www.wahlarchiv.sites.be.ch/wahlen2010 (31 grudnia 2012). 
Ponadto do jego zadań należy:

1) opracowanie wytycznych dla polityki rządu, planu zadań i finansów oraz innych zasadniczych planów dla pojedynczych obszarów działania;

2) w dziedzinie finansów - podejmowanie decyzji dotyczących:
a) kosztorysu budżetu,
b) rocznych sprawozdań z działalności przedsiębiorstw,
c) nakładania podatków,
d) określenia granic zadłużenia,
e) wydatków, o ile nie należą one do kompetencji rządu kantonalnego;

3) wybór:
a) przewodniczącego parlamentu,
b) szefa rządu,
c) pisarza krajowego,
d) prezesa Sądu Najwyższego i Sądu Administracyjnego,
e) pozostałych członków sądów, o ile uprawnienie to nie przysługuje Narodowi,

f) prokuratora generalnego ${ }^{24}$;

4) nadzór nad rządem i zarządzaniem sądami kantonalnymi oraz sprawowanie ogólnego nadzoru nad administracją i innymi podmiotami realizującymi zadania publiczne;

5) inne uprawnienia: ferendum,

a) omawia i decyduje o wszystkich sprawach, które podlegają re-

b) wykonuje przyznane kantonowi przez konstytucję federalną tzw. prawo współdziałania;

c) może zająć oficjalne stanowisko dotyczące konsultacji z władzami federalnymi,

d) rozstrzyga konflikty kompetencyjne pomiędzy najwyższymi władzami kantonu,

e) postanawia o amnestii i zastosowaniu prawa łaski,

f) wykonuje inne zadania powierzone na mocy konstytucji lub ustaw.

Organizację i szczegółowe zasady działania Wielkiej Rady reguluje ustawa z dnia 8 listopada 1988 r. o Wielkiej Radzie i jej regulamin organizacyjny z dnia 9 maja $1989 \mathrm{r}^{25}$. Stosownie do ich uregulowań wymienić należy następujące organy parlamentu:

1) Przewodniczącego Wielkiej Rady (Ratspräsidentin/Ratspräsident) - wybierany jest wraz z dwoma zastępcami na roczną kadencję

\footnotetext{
${ }^{24}$ Konstytucja kantonalna wyraźnie określa płeć osób sprawujących funkcje wymienione w pkt a)-d) if).

${ }^{25}$ Gesetz vom 8. November 1988 über den Grossen Rat (151.21) i Geschäftsordnung vom 9. Mai 1989 für den Grossen Rat (BSG - Bernische Systematische Gesetzessammlung 151.211.1).

${ }^{26}$ Nie można pełnić tej funkcji dwie kadencje jedna po drugiej.
} 
2) Biuro - składa się z 3 członków Prezydium, 5 skrutatorów (Stimmenzähler) ${ }^{27}$ i Prezydenta Deputacji;

3) Konferencję Przewodniczących (Präsidentenkonferenz) - składa się z Prezydium Wielkiej Rady oraz przewodniczących frakcji, stałych komisji parlamentarnych i Deputacji;

4) Deputację (Deputation) - złożona jest $\mathrm{z}$ deputowanych reprezentujących Jurę Berneńską i francuskojęzycznych deputowanych z okręgu wyborczego Biel-Seeland;

5) Komisje:

a) Finansów (Finanzkommission) - 17 członków,

b) Nadzoru Zwierzchniego (Oberaufsichtskommission) - 17 członków,

c) Sprawiedliwości (Justizkommission) - 15 członków.

Ponadto ustawa o Wielkiej Radzie pozwala na powołanie parlamentarnej komisji śledczej (Parlamentarische Untersuchungskommission).

Rząd kantonu Berno składa się z 7 członków. W jego składzie konstytucyjnie zagwarantowane jest miejsce dla przedstawiciela Jury Berneńskiej - wybieralni są na to miejsce francuskojęzyczni wyborcy, którzy mieszkają w okręgach: Cortelary, Moutier i La Neuville.

Kadencja członków rządu trwa tyle samo co parlamentu kantonalnego i są oni wybierani równocześnie z jego składem. Podkreślić należy jednak konstytucyjny zapis art. 85 ust. 2 berneńskiej ustawy zasadniczej, który przewiduje, że obszar całego kantonu stanowi jeden okręg wyborczy.

Poza reprezentantem Jury Berneńskiej do składu rządu wchodzą osoby, które w pierwszym głosowaniu uzyskają bezwzględną większość głosów, a w drugim największą ich liczbę.

W obecnym składzie rządu kantonalnego (wybranym w roku 2010) znajdują się: B. Egger-Jenzer, P. Perrenoud, A. Rickenbacher (SP), H.J. Käser (FDP. Die Liberalen), C. Neuhaus (SVP), B. Pulver (GP) i B. Simon (BDP) ${ }^{28}$.

Rząd kantonu (z zastrzeżeniem właściwości parlamentu) określa cele działalności państwowej. Planuje i koordynuje działania kantonu. Kieruje administracją kantonalną - dzieli się ona na dyrekcje (Direktionen), którymi kierują jego członkowie (jeden z członków rządu może kierować więcej niż jedną dyrekcją).

Aktami prawnymi rządu są rozporządzenia, które wydaje on w granicach konstytucji i ustawodawstwa. Rząd może (z zastrzeżeniem kompetencji parlamentu) zawierać umowy międzykantonalne i międzynarodowe - w jego własnej kompetencji znajduje się zawieranie krótkoterminowych umów interkantonalnych o podrzędnym znaczeniu.

${ }^{27}$ Ich kadencja również wynosi rok, przy czym mogą pełnić swoją funkcję dwie kadencje po sobie.

${ }^{28}$ http://www.rr.be.ch/rr/de/index/der_regierungsrat/der_regierungsrat.html (31 grudnia 2012). 
Poza ww. do kompetencji rządu kantonu Berno należą jeszcze:

1) w zakresie finansów:

a) tworzenie planu zadań i planu finansów, przyjęcie budżetu i sprawozdania rocznego oraz przekazanie ich parlamentowi,

b) decydowanie o:

- nowych jednorazowych wydatkach do $1 \mathrm{mln}$ CHF,

- nowych powtarzających się wydatkach do 200 tys. CHF,

- zobowiązaniu się do poniesienia wydatków;

c) podejmowanie decyzji w przedmiocie sprzedaży gruntów kantonów, jak również ich zakupu na cele inwestycyjne;

2) zadanie wymienione $\mathrm{w}$ art. 90 konstytucji:

a) reprezentacja kantonu (na zewnątrz i wewnątrz),

b) odpowiedzialność za utrzymanie bezpieczeństwa i porządku publicznego,

c) przygotowywanie spraw dla Wielkiej Rady (jeżeli nie może ona zrobić tego samodzielnie),

d) egzekwowanie przepisów i decyzji Wielkiej Rady oraz prawomocnych wyroków,

e) przygotowywanie oświadczeń kierowanych do władz federalnych (jest w tym zakresie związana opinią parlamentu),

f) podejmowanie decyzji $\mathrm{w}$ przedmiocie skarg (jeżeli przewidują to ustawy),

g) podejmowanie decyzji w sprawie korekty granic kantonalnych i komunalnych,

h) realizacja innych zadań, które powierza mu konstytucja lub ustawy.

Szczególnym uprawnieniem rządu kantonalnego jest przyznane mu przez art. 91 konstytucji możliwość podjęcia działań bez podstawy prawnej - wyłącznie w celu zapobieżenia rzeczywistemu i bezpośredniemu zagrożeniu zakłócenia porządku publicznego i bezpieczeństwa, jak również społecznego stanu zagrożenia. Przyjęte wówczas rozporządzenie winny być natychmiast zatwierdzone przez Wielką Radę - traci ono moc w ciągu roku od wejścia w życie.

Administracja centralna podzielona jest na 7 dyrekcji - obejmuje także Kancelarię Kantonu (jednostka pomocnicza rządu i parlamentu kantonalnego). Wśród Dyrekcji wymienić należy:

1) Dyrekcję Gospodarki Narodowej (Volkswirtschaftsdirektion),

2) Dyrekcję Zdrowia i Opieki (Gesundheits- und Fürsorgedirektion),

3) Dyrekcję Sprawiedliwości, Gmin i Kościołów (Justiz-, Gemeindeund Kirchendirektion),

4) Dyrekcję Policji i Wojska (Polizei- und Militärdirektion), 
5) Dyrekcję Finansów (Finanzdirektion),

6) Dyrekcję Oświaty (Erziehungsdirektion),

7) Dyrekcję Budownictwa, Transportu i Energii (Bau-, Verkehrs- und Energiedirektion) ${ }^{29}$.

Obszar kantonu podzielony jest na 26 okręgów urzędowych (Amtsbez$i r k)^{30}, 5$ regionów administracyjnych (Verwaltungsregion) i okręgów administracyjnych (Verwaltungskreise) ${ }^{31}$.

Wymiar sprawiedliwości w kantonie Berno należy do:

1) w sprawach cywilnych:

a) prezesa sądu,

b) Sądu Najwyższego (Obergericht),

c) innych organów określonych przez ustawy (w szczególności do rozpoznawania spraw z zakresu prawa pracy, najmu i handlu);

2) w sprawach karnych:

a) prezesa sądu,

b) sądu okręgowego (Kreisgericht) lub regionalnego sądu kolegialnego (Kollegialgericht),

c) sądu dla nieletnich (Jugendgericht),

d) sądu gospodarczego (Wirtschaftsgericht),

e) Sądu Najwyższego,

f) innych organów administracji kantonalnej i gminnej, którym ustawy przekazały uprawnienia karno-administracyjne (zastrzeżony pozostaje nadzór sędziowski);

3) Sądu Administracyjnego (Verwaltungsgericht) - rozpoznaje w ostatniej instancji spory administracyjne ${ }^{32}$.

Na terenie kantonu Berno występują, zgodnie z art. 107 ust. 2 konstytucji, cztery rodzaje gmin, będących korporacjami prawa publicznego posiadającymi osobowość prawną:

1) gminy mieszkańców (Einwohnergemeinde),

2) gminy obywatelskie (Bürgergemeinde),

29 Art. 27-33 ustawy z dnia 20 czerwca 1995 r. o organizacji Rady Rządowej i administracji (Gesetz vom 20. Juni 1995 über die Organisation des Regierungsrates und der Verwaltung - BSG 152.01).

${ }^{30}$ Aarberg, Aarwangen, Bern, Biel, Büren, Burgdorf, Courtelary, Erlach, Fraubrunnen, Frutigen, Interlaken, Konolfingen, Laupen, Moutier, La Neuville, Nidau, Niedersimmental, Oberhasli, Obersimmental, Saanen, Schwarzenburg, Seftigen, Signau, Thun, Trachsenwald i Wangen - Ibidem, art. 38 ust. 2.

31 1) region i okręg Berner Jura, 2) region Seeland - okręg Biel/Bienne i Seeland, 3) region Emmental-Oberaargau - okręg Emmental i Oberaargau, 4) region i okręg Bern-Mittelland, 5) region Oberland - okręgi Thun, Obersimmental-Saanen, Frutigen-Niedersimmental i Interlaken-Oberhasli. Ibidem, art. 39a ust. 3.

32 Ustawy kantonalne mogą przekazać rozpoznawanie sporów administracyjnych innym wyspecjalizowanym organom wymiaru sprawiedliwości. 
3) gminy mieszane (gemischt Gemeinde),

4) gminy kościelne (Kirchgemeinde) ${ }^{33}$.

Konstytucja gwarantuje gminom ich byt, autonomię, obszar i majątek. Tworzenie, zniesienie ${ }^{34}$ i zmiana obszaru gminy jest uprawnieniem parlamentu kantonalnego.

\section{Zusammenfassung}

Kanton Bern ist Mitglied der Schweizerischen Eidgenossenschaft. Der Artikel bezieht sich u.a. auf die Geschichte des Kantons Bern, welcher 1191 gegründet wurde, seit 1218 freie Reichsstadt ist, 1353 der Eidgenossenschaft beitritt und seit dem 15. Jahrhundert sich als Staat verstand. Im Laufe der Zeit entwickelte sich Bern nicht nur zu einer der größten Städte nördlich der Alpen, sondern auch zu einer politischen Gemeinde, zum Hauptort des Kantons Bern im Verwaltungskreis Bern-Mittelland sowie zur Bundesstadt und somit de facto Hauptstadt der Schweiz. Bern gehört neben Zürich, Genf und Basel - zu den größten Gemeinden der Schweiz.

Im Artikel wird ebenfalls auf die Staatsform des Kantons sowie seine Verfassung (es gilt die Kantonsverfassung von 1993) hingewiesen, zumal Bern ein freiheitlicher, demokratischer und Sozialer Rechtsstaat ist, dessen Parlament (Grosse Rat) 160 Mitglieder angehören.

33356 gmin mieszkańców (stan na dzień 22.05.2012), 195 gmin obywatelskich (stan na dzień 31.12.2011), 26 gmin mieszanych (stan na dzień 22.05.2012) i 245 gmin kościelnych (stan na dzień 16.08.2012) - http://www.jgk.be.ch/jgk/de/index/gemeinden/gemeinden/ gemeindedaten/statistische_datendergemeinden. html (31 grudnia 2012).

${ }^{34}$ Wymagana jest zgoda likwidowanej gminy. 